\title{
THEN AND NOW: \\ Recognition of Women Artists Since 1970
}

\section{BY JOAN MARTER}

Dr. Marter is Professor of Art History at Rutgers, The State University of New Jersey

When the Women Artist Series began in 1971, feminists were painfully aware of their limited opportunities for recognition. Actually, the women's movement had only recently reached the art world. The National Organization for Women had formed seven years earlier, and in August 1970, thousands of women had marched in cities across the United States to celebrate the fiftieth anniversary of the Nineteenth Amendment that guaranteed women's suffrage. Feminists demanded passage of an Equal Rights Amendment-a constitutional amendment which has yet to find sufficient support in this country.

By the early seventies, many women artists had become activists, and challenged commercial galleries and museums to give women equitable representation. Feminists also determined that the art historical canon should include great women artists, and the study of art came to involve new issues, new interpretations, and new voices. As the women's movement flourished, feminists protested museum exhibitions that included only token numbers of women. Organizations such as Women Artists in Revolution (WAR) and the Ad Hoc Committee of the Art Workers Coalition wrote letters of protest and demonstrated at the Museum of Modern Art and Whitney Museum of American Art. Curators at the Whitney, for example, generally chose fewer than 10 percent women for the Whitney Annual. Few if any shows were devoted to women's work. In addition, women artists were seldom written about in art magazines, and found little interest in their art by commercial dealers (although many dealers were women, they preferred male artists). Group exhibitions of contemporary art in major museums largely ignored the achievement of women.

Although the pressure exerted by women's organizations resulted in a few solo exhibitions for women artists of historical importance, contemporary women artists remained barely visible. Several art organizations and gal- 
leries formed to address the needs of these women. Activist groups included the Women's Caucus for Art (originally affiliated with the College Art Association ) and Women in the Arts. Group exhibitions were arranged, and solo exhibitions were planned. Alternative spaces-in banks, corporate offices, and college building-afforded many opportunities for the display of women's achievements, and the Women Artist Series was at the forefront of this effort to bring women's work to the public.

Of the artists most closely identified with the emergence of the women's movement in art, many were selected for solo exhibitions in the Women Artists Series. An examination of the roster of artists shown at Douglass College indicates that many of the leading women artists of the past two decades were given early recognition in the Series. Feminist art has been defined through the works of some of these women, including Mary Beth Edelson, Joyce Kozloff, Miriam Schapiro, Joan Semmel, and Joan Snyder. Artists such as Joan Semmel, Carolee Schneeman, and the late Ana Mendieta attempted to make the female nude an active subject, strongly associated with personal sexuality, and far removed from the sex objects depicted by male artists. Using a full range of techniques and materials, including photography, sculptural installations, and performance, women artists demonstrated their rage against patriarchal oppression.

Feminists were willing to explore their own bodies, their psyche, and their experiences as women as source material for their art. Edelson and Mendieta drew on images of female deities for their role models of figures of power. Others such as Nancy Spero, Faith Ringgold, and Ida Applebroog commented on the plight of women with disturbing images that explicitly refer to violence and abuse. Ringgold is among a number of AfricanAmerican women who have established a strong voice in contemporary art, and she is one of a number of black women celebrated in the Series; Vivian Browne, Candace Hill-Montgomery, Howardena Pindell, and Betye Saar are others. Older women who received much-deserved acclaim during the 1970s were also honored by exhibitions in the Douglass Library: Louise Bourgeois, one of the greatest living sculptors, whose overtly sexual content has transformed sculptural imagery, Alice Neel, whose caustic portraits of friends and family established her as an important American realist, and Dorothy Dehner, who at 90 is among the few surviving artists of the Abstract Expressionist generation. Miriam Schapiro also helped to define the feminist art by her "femmage"-mixed media works that had a strongly biographical component. Among the issues addressed in her impressive artistic achievement is the integration of traditional women's art forms- 
stitchery, quilting, weaving, etc., with "high" art. Sculptors Alice Aycock, Jackie Winsor, and Harmony Hammond were shown in solo exhibitions at Douglass, and continue to be recognized for their achievements. Aycock, for example, has established herself internationally as one of the truly exceptional sculptors of her generation. A 1968 graduate of Douglass College, she has completed many major commissions, and is included in museum collections in this country and abroad.

Given the quality of their work, and the productivity of these artists, one might assume that women emerged victorious from their decades of struggle for representation. Is there no longer a need for women's exhibitions like those sponsored at Douglass College? I would like to report that women have gained full recognition, but this is far from the case. Although juries for group exhibitions, directors of galleries, and curators of museums are more conscious that they should be exhibiting works by women, the actual ratios of men to women receiving attention in the art world has remained constant. Although there were some gains by women during the 1970 s, the "Reagan years" saw a reversal of this trend. Only in recent years have feminists gained some ground. The truth is that some women have been successful, but many accomplished and committed women artists remain relatively unknown.

The dilemma facing women artists in the nineties is that a selected group of women artists may be considered representative of all women's art, and the success of a few "superstars" will be viewed as compensation for the neglect of many others. In this age of multiculturalism, it is essential that the art produced by all women, African-American, Native American, AsianAmerican, Latina, and all others will continue to be recognized. It is, therefore, both desirable and necessary to organize exhibitions that present broad-ranging entries by women, and that the specialized imagery, and impressive achievements of women artists continue to be celebrated. 